\title{
VITAROVAT
}

\section{Megjegyzések Kalmár János - Kuti László - Kátai János - Figler Renáta és Füleky György: „Kovárványcsíkok képződése a Nyírség homoktalajában" címü tanulmányához}

\author{
BURÓ Botond ${ }^{1}$, LÓKI József ${ }^{2}$, NÉGYESI Gábor ${ }^{2}$, NOVÁK Tibor József ${ }^{2}$ \\ ${ }^{1}$ Izotóp Klimatológiai és Környezetkutató Központ, MTA Atomki, Debrecen, Hungary \\ ${ }^{2}$ Debreceni Egyetem, Természettudományi és Technológiai Kar, Földtudományi Intézet, \\ Debrecen, Hungary

\section{Megjegyzések: AgROKÉMIA ÉS TALAJTAN 66 (2017) 1, 9-34} \\ DOI: $10.1556 / 0088.2017 .66 .1 .2$
}

Kalmár János és szerzőtársai egy értékes tanulmányt közöltek a nyírségi kovárványcsíkokról. Hosszú idő után újra időszerű foglalkozni ezekkel a vasban és agyagban gazdag vöröses barna talajrétegekkel, amelyeket nem csak Magyarországon, hanem a Föld más negyedidőszaki üledékeiben is leírtak, ugyanis mind a mai napig vitatott e rétegek kialakulásának a folyamata, keletkezésének ideje és nincs egységes elfogadott álláspont erről a kérdésről.

A tanulmányban a szerzők Tamásipuszta határából mutatnak be egy kovárványos barna erdőtalaj szelvényt, rendkívüli alapossággal. A közölt eredmények, különösen a mikrobiológiai és ásványtani elemzések részletesek és újszerüek.

Mivel azonban számos tekintetben a gyakorlati, terepi tapasztalatainkkal és korábbi kutatási eredményeinkkel, illetve a szakirodalomban fellelhető tanulmányokban szereplő elméletekkel ellentmondó megállapításokat tartalmaz, ezért szükségét láttuk, hogy a tanulmánnyal kapcsolatos meglátásainkat vitarovatban közzétegyük.

\section{Bevezetés}

A Nyírségi homokbuckákban a kovárványként leírt rétegek szinte kivétel nélkül jelen vannak, azonban vastagságuk terepi tapasztalataink alapján nem szorítkozik kizárólagosan több tíz cm-re, hanem a néhány mm vastagságútól akár ténylegesen több tíz $\mathrm{cm}$ vastagságig terjedhet. Jóllehet az idők folyamán ezek a vastagabb rétegek össze is nőhettek.

A szerzők „vöröses barna színü, lencsés vagy szabálytalan alakú betelepülések"-nek nevezik a kovárványt, majd később azt írják, hogy általánosan elfogadott tény, hogy ezek a rétegek helyben képződtek. Ezzel a szerzők önmaguknak mondanak ellent.

Postai cím: BuRó Botond, Izotóp Klimatológiai és Környezetkutató Központ, MTA Atomki, 4026 Debrecen, Bem tér 18/c. Debrecen, Hungary

E-mail: bbotond86@gmail.com 
A tanulmány célkitúzései nem világosak, illetve egyetlen talajszelvény mégoly részletes - vizsgálata alapján nem megválaszolhatóak.

A tanulmány egyik célja a kovárványok genetikájának tisztázása, ám erre az alkalmazott módszerek több okból sem alkalmasak:

- Nem definiálják, hogy mit tekintenek kovárványnak, így a kovárvány, és nem kovárvány jellegủ talajrétegekből származó minták elkülönítésének mikéntje nem egyértelmü.

- Csak egyetlen kovárványos homokszelvényt vizsgáltak, igaz, azt rendkívüli alapossággal, több, különféle módszerrel. Ez véleményünk szerint nem reprezentálja kellőképpen a nyírségi kovárványcsíkok sokféle megjelenését és esetenként akár eltérő genetikáját.

Az első számú célkitüzés, mely szerint a buckákat képző homok bélyegeit vizsgálják, nem jelent újdonságot, mivel azt már korábban számos kutató vizsgálta és egyértelmüen tisztázta (KÁDÁR 1957, KRIVÁN 1958, STEFANOVITS 1953).

Szintén a célkitüzések között szerepel a kovárványok és a köztük lévő homokrétegek összetételében mutatkozó esetleges különbségek feltárása. Ezt számos szempontból korábban is vizsgálták (VERTSE, 1939, KÁDÁR, 1951, 1957, KLÉH és SZÜCS, 1954; STEFANOVITS, 1953, BORSY 1961, GÁBRIS, 1970, HORVÁTH, 1985). A nemzetközi szakirodalomban szintén számos adat áll rendelkezésre a kovárványcsíkok és a köztes homokrétegek különbségeinek illusztrálására (WURMAN et. al. 1959, DiJKERMAN et al., 1967, BERG, 1984, KEMP és MCINTOSH, 1989, HollidAY és RAWLING, 2006, FURQUim et al., 2013).

A szerzők a buckákban szemcsösszetételi rétegzettségét, illetve a kovárványokban az átlagos szemcseméret-csökkenést biológiai eredetủ korróziónak tulajdonítják. Azonban a buckákban lévő durvább-finomabb rétegek váltakozása dominánsan a szélerő váltakozásának a függvénye. A buckák rétegzettsége megfigyelhető olyan futóhomok területeken is, ahol a rétegsorban nem alakult ki kovárvány.

A tanulmányban újszerủ a vizsgált szelvény esetében a részletes ásványtani elemzés, illetve a mikrobiológiai aktivitásban mutatkozó különbségek bemutatása.

Harmadikként a vasmozgás és a kovárványok kapcsolatának kérdése vetődik fel, amely azonban ilyen formában nem kérdéses, hiszen a legtöbb nemzetközi definíció a kovárványokat vastartalmú akkumulációs képződményekként (BOCKHEIM és HARTEMINK, 2013, SCHAETZL, 1992, 2001) definiálja.

A kérdést inkább úgy lenne érdemes vizsgálni, hogy a vasmozgás a jelenlegi klimatikus és környezeti körülmények között recens folyamat-e, és ha nem, akkor melyik időszakban, minek hatására volt aktív.

A negyedik, talajvízzel való kapcsolatra vonatkozó kérdést a szerzők elvetik, jelezve, hogy a talajvíztükör a buckás terület alatt mintegy 8-10 méter mélységben található. Az elvi lehetősége megvan az ilyen típusú kovárványképződésnek, de gyakorlatilag talajvíz által létrehozott kovárványt sem Magyarországon, sem külföldön nem írtak le. 
Továbbá a szerzők azt írják, hogy a talajvíztükör a legmagasabb talajvízállás esetén sem lehet magasabb, mint a buckaközi mélyedések felszíne. Ez a megállapítás téves, mivel a talajvíztükör szintje követi a felszínt, tehát lehet magasabb a talajvíz szintje, mint a buckaközi mélyedés, ezt a tényt már RóNAI (1961) is leírta.

A célkitủzés utolsó pontjaként annak megválaszolása szerepel, hogy a vasásvány-akkumulációt a kovárványokban geogén, vagy pedogén folyamatok okozzák?

Ez a kérdés a nemzetközi szakirodalomban kiterjedt vita tárgya, ugyanakkor a különböző kovárványtípusok elkülönítésének egyik alapja. Ezek alapján három fő típust különböztet meg a szakirodalom, és ezeken a csoportokon belül is különböző okokat neveztek meg a szerzők, amelyek a kovárvány rétegek kialakulásában közrejátszanak. Ennek az alapjait WURMAN et. al. (1959) és DIJKERMAN et al. (1967) munkái tartalmazzák, majd RAWLING (2000) rendszerezte.

- A petrogenic eredetủ kovárvány kialakulását elsősorban a talajképző üledék rétegződése határozza meg (ROBINSON és RicH, 1960, BULLOCK és MACKNEY, 1970).

- A pedogenic eredetü lamellák létrejöttét különböző talajtani folyamatok, elsősorban a talajban képződő és lefelé mosódó (illuviális) agyag mérettartományba tartozó vasas csapadék kiválása okozza, helyzetét pedig a beszivárgás mélysége határozza meg (WURMANN et al., 1959, GILE, 1979, TORRENT et al., 1980, SCHAETZL, 1992, MiLES és FrANZENMEIER, 1981, BERG, 1984).

- A pedo-petrogenic eredetủ lamellák tulajdonképpen az előbbi két típus keverékének tekinthetők. A szelvényben lefelé mozgó bemosódott agyag kicsapódásával keletkeznek, mely folyamatot a talajképző kőzet (negyedidőszaki homok) tulajdonságai (rétegzettsége) szabályoznak (DIJKERMAN et al., 1967, GILE, 1979, CoEN et al., 1966).

Egyetlen szelvény alapján nem lehet a kovárványok keletkezését tisztázni, mivel az nem reprezentálja a hazai kovárványos talajok teljes spektrumát.

\section{Vizsgálati anyag és módszer}

A mintavételi hely neve helyesen Tamásipuszta, Nyíradony településrésze. Kifogásolható, hogy a mintaterület bemutatása során mellőzték a szép számmal rendelkezésre álló releváns hazai szakirodalmak eredményeit (BORSY, 1961, 1974, 1977, 1987, 1989, BORSY et al., 1985, LÓKI, 2003, 2006, LÓKI et al., 1994, 2012, KIss et al., 2012). A hordalékkúp anyaga az Ös-Tisza, Ös-Bodrog és ezek mellékfolyóinak hordalékából származik. Továbbá nem szerencsés a Nyírség helyzetét a Szilágysági Dombvidékhez viszonyítani, mivel az genetikailag nem köthető a Nyírséghez. A Nyírségben a fő homokmozgási periódus nem a későglaciálisban volt, hanem már a felső-pleniglaciálisban elkezdődött, majd a későglaciálisban folytatódott, illetve a holocén szárazabb, hidegebb periódusaiban is kimutatták a homok mozgását (UJHÁZY et al., 2003; SIPOS et al., 2006). 


\section{Vizsgálati eredmények és értékelésük}

\section{Morfológiai vizsgálatok}

A terepi szelvényleírás értékes fejezete a tanulmánynak és a hazai kovárványkutatásnak, amely által újabb adatokhoz jutottunk a nyírségi kovárványról. Azonban a színeket célszerübb lett volna Munsell-színek feltüntetésével megadni.

Az 1. táblázatban nem világos, hogy az egyes minták helyzete és mélysége hogyan következik, a feltüntetett rétegsor hiányos. A módszerek között fúrással történt mintavételröl nem esik szó.

\section{Talajtani vizsgálatok}

A Talajtani vizsgálatok címü fejezetben leírt eredményekkel ellentétben, saját vizsgálataink során a humusztartalomban nem mutatkozott szignifikáns különbség, ahogyan a vizes $\mathrm{pH}$ esetében sem, még ha az értékek esetlegesen eltérést mutatnak a kovárványban és a köztes homokrétegben. Humusztartalom esetében ellenkezö megállapításra jutottunk, mint a szerzők: a kovárványban általában magasabb volt humusz mennyisége, noha statisztikailag szignifikáns különbség nem állt fent. Magyarázatra szorul az is, hogy a szervesanyagból hogyan képződik vasoxihidroxid.

\section{Koptatottsági vizsgálatok}

A koptatottsági vizsgálatok során a szerzők azt a megállapítást teszik, hogy kovárványrétegekben jóval több a szegletes, éles élü-hegyes sarkú szemcse részaránya, mint a köztes homokban. Ezt a korróziót a gyökérsavak és a gyökérnyomás korróziójának tulajdonítják. Valószínűsíthető az adott folyamat, de nem úgy, hogy minden egyes kovárvány réteg egykor recens talaj volt, és az azon képződött növényzet okozta rétegenként a szemcsék korrózióját. A koptatottságra jóval ésszerübb magyarázat lehet, hogy a jelenlegi felszínen kialakult növényzet okozta ezt a korróziót, ugyanis saját megfigyeléseink szerint a növénytakaró gyökérzete mélyen lehatol, és a kovárványrétegekben szerteágaznak a hajszálgyökerek, a kedvezőbb vízellátottság miatt, míg a köztes homokrétegeken csak áthatolnak.

\section{Következtetések és összefoglalás}

A szerzők a tamásipusztai feltárás kovárványrétegeit részben széleróziót szenvedett, betemetett egykori recens talajszinteknek tulajdonítják.

Ezt a következtetést több szempontból sem tartjuk általánosnak a kovárványokra nézve:

- Amennyiben minden egyes kovárvány réteget egykori recens talajnak tulajdonítanak, akkor ennek tükrében igen gyors talajképződési folyamatoknak kellett lejátszódniuk az egész Nyírségben. Ehhez stabil felszín, nedves meleg klíma, továbbá megfelelően zárt növénytakaró kellett. Nem tartunk valószínủnek olyan gyors talajképződési és homokmozgási fázisokat, mint, amennyi kovárvány réteg 
van egy-egy feltárásban. Az általunk részletesen vizsgált szelvényekben akár 5-17 különböző vastagságú kovárvány réteget is találtunk. Például Baktalórántháza (BURÓ, 2015, BURÓ et al., 2016) feltárásban hasonló megjelenésủ kovárványrétegeket írtunk le, mint a tamásipusztaiak. Ebből a feltárásból Optikailag Stimulált Lumineszcens (OSL) koradatokkal is rendelkezünk. A $230 \mathrm{~cm}$ és $310 \mathrm{~cm}$ es mélysében mért OSL korok a következőek: $14100 \pm 860$ év, $15240 \pm 870$ év. Ebben a $80 \mathrm{~cm}$ vastag rétegben 5 különböző vastagságú kovárvány réteget írtunk le. Ez azt jelentené, hogy 1140 év alatt 5 talajképződési és homokmozgási periódus ment volna végbe. Ez meglehetősen rövid időintervallum 5 talajréteg kifejlődéséhez.

- A Nyírségben több helyen találtunk eltemetett fosszilis talajt a buckák anyagában, amelyek merőben másként nézetek ki, mint a kovárvány rétegek. Sokkal vastagabbak voltak, színük jelentősen eltért, szürkés barna, sötét szürkés barna $(2.5 \mathrm{Y} 5 / 2(\mathrm{sz}) ; 2.5 \mathrm{Y} 4 / 2$ (n) volt, szemben a kovárvány barna, sötét barna, sötét sárgás barna (7.5YR 4/4 (sz) 7.5YR3/4 (n); 10YR3/6 (n), 10YR4/4 (sz) színével. Nagyobb volt bennük a humusztartalom is, mint a kovárványrétegekben. Tehát ez alapján sem tartjuk valószínünek, hogy a kovárvány rétegek egykori felszíni talajok lettek volna.

- A szerzők által említett példák (Rém és Borota) nem minden esetben megfelelőek. Egyrészről a Duna-Tisza közén nincs kovárvány, így irreleváns, hogy ott a homokbányák beerdősödtek. Ez akkor lehetne érdekes, ha olyan egykori homokbányában sikerülne kimutatni a kovárványrétegek képződését, ahol 20-30 évvel ezelőtt azok nem fordultak elö, ugyanakkor a beeredősülés hatására ezen rétegek képződése napjainkban kimutatható lenne.

- A hivatkozott és példaként említett német félig kötött futóhomok terület moréna eredetü bucka, amely esetében teljesen más klimatológiai feltételek uralkodtak, mint a Nyírségben.

\section{Általános vélemény}

Jelen hozzászólás szerzői úgy vélik, hogy a vasmozgás a mindenkori topográfia függvényében a magasabb térszíneken beszivárgó csapadékvíz hatására megy végbe, amely kisebb csapadékesemény során beázási profilszerúen csak bizonyos mélységig hatol le, teljes átnedvesedés esetén pedig eljut a talajvízbe. A profilszerủ beázások során elmozdult és megrekedt vasásványok kiszáradása során a későbbi vízmozgást kisebb-nagyobb mértékben gátolják, így további felhalmozódást, akkréciót, vastagodást generálnak.

A kovárványokban relatíve feldúsulni képes vasásványok véleményünk szerint részben jelen vannak az eredetileg felhalmozott ártéri, illetve alluviális üledékekben, kisebb részben pedig a biológiai aktivitás következtében (erdő alatt gyorsabban, gyep alatt kisebb mértékben, BALOG et al., 2014) helyben mállással keletkeznek az üledék finomfrakciójából. Relatív felhalmozódásuk sávos, laminás megjelenése pedig a laza textúrájú homokban gyorsan leszivárgó víz hatására történő elmozdulás következménye. A folyamat analóg a podzolok spodic 
szintjének, illetve az azok alatt elhelyezkedő lamelláknak a képződésével, bár természetesen annak a mértékét meg sem közelíti.

A buckaközi laposokban kiváló vasásványok ezzel szemben a buckákon mélybe szivárgott, oldott (olykor redukált, két vegyértékü) vasban feldúsult talajvízből kemoautotróf baktériumok tevékenységével jönnek létre. Ezek megjelenése, topográfiai helyzete azonban élesen elüt a kovárványokétól.

A Nyírségben előforduló, az üledék eredeti rétegzettségét követő kovárványok genetikája azonban a fenti módon nem magyarázható, még akkor sem, ha a rétegzettség okozta szemcseösszetételben mutatkozó változások eleve okozhatnak egyenetlenséget a lefelé szivárgó nedvesség sebességében és ezzel a vele mozgó vasásványok vertikális koncentrációjában.

Úgy gondoljuk, hogy a kovárványoknak nincs egységes képződési módja, ahogyan teljesen egységes megjelenése sem, azt számos helyi domborzati, klimatikus, vízforgalmi, növényzeti és ásványtani folyamat befolyásolja, amelynek eredményeképpen csupán hasonló, de nem uniform megjelenésü képződmény azonosítható. Ezt az is mutatja, hogy az általunk osztályozott talajszelvények esetében a kovárványos talaj helyenként valóban (Lamellic) Luvisolnak bizonyult, míg legtöbb esetben valóban, a szerzők által megállapított módon, az Arenosoloknál soroltak ki. Úgy véljük, hogy a nagy térbeli elterjedés és a megjelenés változatossága folytán egyetlen szelvényből nem vonhatók le messzemenő következtetések a szerzők által feltett kérdésekre.

\section{Irodalom}

Balog, K., Gribovszki, Z., Szabó, A., Jobbágy, E., Nosetto, M., Kuti, L., PÁszTOR L., TóTH T. 2014. Alföldi telepített erdők hatása a felszín alatti sófelhalmozódásra sekély talajvizü területeken. Agrokémia és Talajtan. 63. (2) 249-268.

BERG, R. C., 1984. The origin and early genesis of clay bands in youthful sandy soils along Lake Michigan, USA. Geoderma, 32. 45-62.

BOCKHEIM, J. G., HARTEMINK, A. E., 2013. Classification and distribution of soils with lamellae int he USA. Geoderma. 206. 92-100.

BoRsY, Z., 1961. A Nyírség természeti földrajza. Akadémiai Kiadó. Budapest. pp. 227.

BORSY, Z., 1974. A futóhomok mozgásának törvényszerüségei és védekezés a szélerózió ellen. Akadémiai doktori értekezés. Kézirat. pp. 322.

BoRSY, Z., 1977. A magyarországi futóhomok területek felszínfejlődése. Földrajzi Közlemények. 27. 12-16.

BORSY, Z., 1987. Az Alföld hordalékkúpjainak fejlődéstörténete. Nyíregyházi Főiskola Füzetei. pp. 5-37.

BORSY, Z., 1989. Az Alföld hordalékkúpjainak negyedidőszaki fejlödéstörténete. Földrajzi Közlemények. 38. (3-4) 211-222.

BORSY, Z., CSONGOR, É., LÓKI, J., SZABÓ, I., 1985. Recent results in the radiocarbon dating of windblown sand movements in the Tisza-Bodrog Interfluve. Acta Geogr. Debrecina. 22. 5-16. 
Bullock, P., MackneY, D., 1970. Micromorphology of strata in the Boyn Hill Terrace deposits, Buckinghamshire. Micromorphological Techniques and Applications, Agricultural Research. Council Soil Survey. Technical Monograph. 2. 97-107.

BURÓ, B., 2015: Recens és szubrecens felszínformáló folyamatok vizsgálata a nyírségi homokterületen. — PhD Értekezés. Debreceni Egyetem Földtudományi Doktori Iskola. pp. 150.

Buró, B., Sipos, G., LóKI, J., ANDRÁsi, B., FÉlegyházI, E., NÉGYesi, G., (2016): Assessing Late Plesitocene and Holocene phases of aeolian activity on the Nyírség Alluvial Fan, Hungary. Quaternary International. 425. 183-195.

CoEn, G. M., PAWLUK, S., ODYNSKY, W., 1966. The origin of bands in sandy soils of the stony plain area. Canadian Journal of Soil Science. 46. 245-254.

Dijkerman, J. C., Cline, M.G., Olson, G.W., 1967. Properties and genesis of textural subsoil lamellae. Soil Science. 104. 7-16.

Furquim, S. A. C., Coltrinari, L., Ferreira, D. R. P., Castro, S. S., Pugliese, G. R., 2013. Lamellae formation processes in tropical soils in southeastern Brazil. Catena. 107. 15-25.

GÁBRIS, G., 1970. A Sajó-Hernád hordalékkúp geomorfológiai problémái. Egyetemi doktori értekezés. Kézirat. pp. 78.

GILE, L. H., 1979: Holocene soils in eolian sediments of Bailey County, Texas. Soil Science Society of America Journal. 43. 994-1003.

HollidAY, V.T., RAWLING, J. E., 2006. Soil-geomorphic relations of lamellae in eolian sand on the High Plain of Texas and New Mexico. Geoderma. 131. 154-180.

HoRVÁTH, I., 1985. A kovárványrétegek kialakulása, és gazdasági jelentősége a Nyírség és a Bodrogköz területén. Szakdolgozat. Kossuth Lajos Tudomány Egyetem. Debrecen. pp. 53.

KÁDÁR, L., 1951. A Nyírség geomorfológiai problémái, A Földrajzi Könyv, és Térképtár Értesítője. II. (10-12). 117-131.

KÁDÁR, L., 1957. A kovárványos homok kérdése. Földrajzi Értesítő. IV. (1). 1-13.

KEMP, R. A., MCINTOSH, P.D., 1989. Genesis of a texturally banded soil in Southland, New Zealand. Geoderma. 45. 65-81.

KISS, T, SIPOS, Gy, MAUZ, B, MEZŐSI, G. 2012. Holocene aeolian sand mobilization, vegetation history and human impact on the stabilized sand dune area of the southern Nyírség, Hungary. Quaternary Research. 78. 492-501.

KLÉH, G., SzÜCS, L. 1954. A Nyírség talajviszonyai. Agrokémia és Talajtan. 3. (1-2) 47-66.

KRIVÁN, P., 1958. Jéglencsés, leveles állótundra jelenségek Magyarországon. Földtani Közlöny. 88. (2) 201-209.

LÓKI, J., 2003. A szélerózió mechanizmusa és magyarországi hatásai. MTA doktori értekezés. Debrecen. pp. 265. + Mellékletek

LÓKI, J., 2006. Holocén felszínváltozás a hazai futóhomok területeken, Holocene land transformation in Hungarian wind-blown sand areas. Scientific Publications of the III. Hungarian Geographical Conference. CD publication. MTA FKI. 1-10.

LÓKI, J., HERTELENDI, E., BORSY, Z., 1994. New dating of blown sand movement in the Nyírség. Acta Geographica Debrecina. Debrecen. pp. 67-76.

LÓKI, J., NÉGYESI, G., BURÓ, B., FÉLEGYHÁZI E., 2012. Aeolian surface transformations on the alluvial fan of the nyírség. Journal of environmental geography. V. (1-4) 112. 
MiLES, R. J., FRANZENMEIER, D.P., 1981. A lithochronosequence of soils formed in dune sand. Soil Science Society of America Journal. 45. 362-367.

RAWLING, J. E., 2000. A review of lamellae. Geomorphology. 35. 1-9.

RoBINSON, G. H., RICH, C. I., 1960. Characteristics of the multiple yellowish- red bands common to certain soils in the south-eastern United States. Soil Science Society of America Proceedings. 24. 226-230.

RÓNAI, A., 1961. Az Alföld talajvíztérképe: magyarázó a talajvíztükör felszínalatti mélységének 1:200 000-es méretű térképéhez. Magyar Állami Földtani Intézet. Budapest pp. 55-65.

SCHAETZL, R. J., 1992. Texture, mineralogy, and lamellae development in sandy soils in Michigan. Soil Science Society of America Journal. 56. 1538-1545.

SCHAETZL R. J., 2001. Morphologic evidence of lamellae forming directly from thin, clayey bedding planes in a dune. Geoderma. 99. 51-63.

SIPOS, G., KISS, T., NYÁRI, D., 2006. OSL mérés lehetőségei. Homokmozgások vizsgálata Csengele területén. Environmental Science Symposium Abstracts. Budapest. 43-45.

STEFANOVITS, P., 1953. A Nyírségi kovárványos homok. MTA Agrártudományi Osztály Közleményei. III. (1-4) 1-11.

Torrent, J., Nettleton, W. D., Borst, G., 1980. Clay Illuviation and lamellae formation in a psammentic Haploxeralf in southern California. Soil Science Society of America Journal. 44. 363-367.

UjHÁZY, K., GÁBris, G., FrECHEN, M., 2003. Ages of periods of sand movement in Hungary determined through luminescence measurements. Quaternary International. 111. 91-100.

VERTSE, A., 1939. A Nyírség felszíni és földtani viszonyai. Vármegyei Szociográfiák. IV. $9-14$

Wurman, E., Whiteside, E. P., Mortland, M. M., 1959. Properties and genesis of finer textured subsoil bands in some sandy Michigan soils. Soil Science Society of America Proceedings. 23. 135-143. 